\title{
Income Effects of Federal Reserve Liquidity Facilities
}

\author{
Michael J. Fleming and Nicholas J. Klagge
}

\section{One of the chief actions taken by the Federal Reserve in response to the financial crisis was the introduction or expansion of facilities designed to provide liquidity to the funding markets. A study of the programs suggests that the liquidity facilities generated $\$ 20$ billion in interest and fee income between August 2007 and December 2009, or $\$ 13$ billion after taking into account the estimated $\$ 7$ billion cost of funds. Moreover, the Fed took important steps to limit the credit exposure it incurred in connection with the facilities.}

\footnotetext{
A fter the start of the financial crisis in August 2007, the Federal Reserve adopted many measures to mitigate the disruptions in financial markets, including the introduction or expansion of liquidity facilities. Many studies have found that the facilities were effective in promoting financial stability during the crisis. ${ }^{1}$ In addition, because the facilities were designed according to well-understood lender-of-last-resort principles-the Fed's loans were well collateralized and generally priced at a premium to the cost of funds-they also earned considerable income.
}

While income generation is not the aim of the Fed's policies, it is through such income that the Fed covers its expenses. Moreover, excess Federal Reserve income is turned over to the U.S. Treasury, offsetting the government's need to raise such funds from other sources. In 2009, for example, the Federal Reserve Banks transferred $\$ 47.4$ billion of their $\$ 52.4$ billion net income to the Treasury.

In this edition of Current Issues, we use publicly available data to assess the effects of the Federal Reserve's liquidity facilities on its interest and fee income. ${ }^{2}$ We estimate that the facilities contributed $\$ 20$ billion to the central bank's interest and fee income between August 2007 and December 2009, the period of the facilities' greatest usage. Meanwhile, the cost of the funds lent through the facilities amounted to only an estimated $\$ 7$ billion, so that the facilities generated an estimated $\$ 13$ billion in income in excess of the cost of funds.

The additional income generated by the Federal Reserve facilities came with additional credit risk, and some of the extra income should be considered compensation for this risk. However, the Fed took numerous facility-specific steps to keep credit risk to a minimum in operating its programs, such as limiting borrowing to institutions that met eligibility criteria, providing the loans on a short-term basis, and requiring that loans be backed by adequate collateral. As a result, the central bank has not borne any credit losses to date through its new or expanded liquidity facilities.

It is important to note that the Fed publishes income information in its annual report and in its monthly report "Credit and Liquidity Programs and the Balance Sheet." These reports contain actual income figures for many of the liquidity facilities and therefore offer an advantage over the estimates presented here. Our analysis, however, serves somewhat different purposes. Specifically, it shows in a simple way how facility income can be estimated from public information. It also includes estimated income figures for some facilities not broken out in the official reports and provides figures for more granular intervals of time. Moreover, our analysis considers the facilities' cost of funds and compares that cost with the income from the facilities.

\footnotetext{
${ }^{1}$ See, for example, Cecchetti (2009) and Willardson and Pederson (2010).

${ }^{2}$ Because we focus on the liquidity facilities, we do not assess the income effects of the Fed's asset purchase programs, support for specific institutions, or regular open market operations.
} 


\section{Federal Reserve Responses to the Crisis}

To address the disruptions in financial markets during the crisis, the Federal Reserve introduced or expanded liquidity facilities, provided support for specific institutions, and engaged in direct purchases of assets. $^{3}$

\section{Liquidity Provision to Banks}

The Fed initially addressed liquidity pressures in the unsecured funding markets relied on by depository institutions. On August 17, 2007, shortly after the start of the crisis, the Fed announced temporary changes to its primary credit discount window facility to reduce depository institutions' uncertainty about the cost and availability of funding. In particular, the Federal Reserve reduced the primary credit rate, narrowing the spread of the rate over the federal funds target rate, and extended the allowable term of lending to as long as thirty days. The Fed later narrowed the spread of the primary credit rate over the federal funds target rate further and increased the maximum maturity of loans to ninety days.

On December 12, 2007, the Fed announced two new initiatives to address funding pressures in short-term lending markets. First, the central bank established the Term Auction Facility (TAF), through which it auctioned loans to depository institutions, typically for terms of twenty-eight or eighty-four days. Second, the Fed established reciprocal currency arrangements, or swap lines, with the European Central Bank and the Swiss National Bank. The arrangements addressed dollar funding pressures outside the United States by allowing foreign central banks to lend U.S. dollars to banks in their jurisdictions. The swap lines were later extended to an additional twelve foreign central banks.

\section{Liquidity Provision to Dealers}

In March 2008, around the time of the near-collapse of Bear Stearns, the Fed took several steps to address liquidity pressures in the secured funding markets relied on by dealers. On March 7, the Fed announced that it would initiate a series of single-tranche open market operations (OMOs) with the primary dealers-dealers that have a trading relationship with the Fed-in which dealers could bid to borrow funds through term repurchase agreements for a term of twenty-eight days.

On March 11, the Fed announced the introduction of the Term Securities Lending Facility (TSLF), through which it auctioned loans of Treasury securities to primary dealers for terms of twenty-eight days. As part of the TSLF, the Fed later announced the start of the Term Securities Lending Facility Options Program (TOP), through which the Fed auctioned options on draws on the TSLF.

The Fed then announced on March 16 the creation of the Primary Dealer Credit Facility (PDCF), a standing facility through which the Fed made overnight loans to primary dealers. The rate charged was the same as the discount window's primary credit rate, with an additional fee assessed to frequent borrowers. The Fed later announced

\footnotetext{
3 This discussion follows a more detailed overview in the appendix to the Federal Reserve's February 24, 2009, Monetary Policy Report to the Congress, available at http://www.federalreserve.gov/monetarypolicy/mpr_default.htm.
}

liquidity support for certain securities subsidiaries of Goldman Sachs, Morgan Stanley, and Merrill Lynch, and for Citigroup's London-based broker-dealer subsidiary, under terms similar to that of the PDCF.

\section{Liquidity Provision to Other Market Participants}

Money market disruptions emanating from the bankruptcy of Lehman Brothers led the central bank to introduce several additional liquidity facilities. On September 18, 2008, the Fed announced the creation of the Asset-Backed Commercial Paper Money Market Mutual Fund Liquidity Facility (AMLF). Through this facility, the Fed made loans at the primary credit rate to depository institutions and bank holding companies to finance their purchases of highquality asset-backed commercial paper (ABCP) from money market mutual funds. The AMLF helped money funds holding ABCP to meet redemption demands from investors and promoted liquidity in the ABCP and broader markets.

The Fed announced the creation of the Commercial Paper Funding Facility (CPFF) on October 7, 2008, to provide a backstop to issuers of commercial paper and thereby improve liquidity in short-term funding markets. Through the facility, the Fed provided credit to a special-purpose vehicle (SPV) that, in turn, bought newly issued three-month commercial paper from eligible issuers. Prices were based on a market rate plus a fixed spread. Borrowers also had to pay a registration fee to participate in the program, and certain borrowers had to pay a credit enhancement fee.

On October 21,2008, the Fed announced the establishment of the Money Market Investor Funding Facility (MMIFF). Through the MMIFF, the Fed could provide secured loans to a series of private sector SPVs to finance the purchase of certain money market instruments from eligible investors. The facility, which was never used, was thus intended to improve the liquidity of money market investors and enhance their ability to meet redemption requests and their willingness to purchase money market instruments.

Finally, the Fed announced on November 25, 2008, its intent to create the Term Asset-Backed Securities Loan Facility (TALF). The Fed made loans through the TALF to eligible owners of certain assetbacked securities (ABS). Rates on the loans varied according to the type of collateral securing the loan, and the Treasury provided credit protection to the Fed through the Troubled Asset Relief Program. The TALF supported the issuance of ABS and thereby increased credit availability and economic activity.

\section{Large-Scale Asset Purchases}

To improve market conditions, the Fed also instituted programs to purchase assets directly. Under programs first announced in November 2008 and March 2009, the Fed ultimately purchased \$1.25 trillion of agency mortgage-backed securities (MBS), \$172 billion of agency debt securities, and $\$ 300$ billion of longer term Treasury securities by the end of March 2010. In August 2010, the Fed announced it would reinvest principal payments from its agency MBS and agency debt securities in longer term Treasury securities, and in November 2010 it announced its intent to purchase an additional $\$ 600$ billion in longer term Treasury securities by the end of June 2011. 


\section{Support for Specific Institutions}

The Fed also provided support for specific institutions to promote financial market stability. In March 2008, it provided special financing to facilitate the acquisition of Bear Stearns by JPMorgan Chase. In September and October 2008, the Fed provided support for AIG (American International Group) to assist the firm in meeting its obligations, to facilitate the orderly sale of some of its businesses, and to finance fixed-income securities it held. In November 2008 and January 2009, the Fed agreed to provide credit under certain conditions to Citigroup and Bank of America, respectively.

\section{Balance Sheet Implications}

The Federal Reserve's efforts to mitigate the strains in financial markets led to an unprecedented expansion of its balance sheet (Chart 1). Federal Reserve assets rose from $\$ 869$ billion on August 8, 2007, to $\$ 2,256$ billion on December 17,2008, and stood at $\$ 2,237$ billion on December 30,2009. Assets increased fairly modestly through much of the first year of the financial crisis, as growth of the liquidity facilities was offset by decreases in securities held outright. In fall 2008, however, the liquidity facilities and total assets both grew sharply.

Changes in the amounts outstanding under the liquidity facilities are largely explained by the evolution of the three largest programs: the central bank liquidity swaps, the CPFF, and the TAF (Chart 2). Amounts outstanding were essentially zero before the introduction of the TAF and the liquidity swaps in December 2007. The facilities grew sharply in fall 2008 - with the expansion of the TAF and the liquidity swaps and the introduction of the CPFF- to $\$ 1,599$ billion outstanding on December 10, 2008.

Outstanding amounts under the facilities subsequently declined to $\$ 168$ billion on December 30, 2009, as market conditions improved and the facilities were largely wound down. ${ }^{4}$ The last single-tranche $\mathrm{OMO}$ outstanding matured January 28, 2009; the MMIFF was not extended past its October 30,2009, expiration; and the AMLF, central bank swap lines, CPFF, PDCF, and TSLF all expired February 1, 2010. ${ }^{5}$ The final TAF auction occurred March 8, 2010, and the extension of credit through the TALF expired March 31, 2010, or June 30,2010, depending on the type of ABS being financed. Temporary changes to the discount window were also reversed in early 2010.

\section{Income Effects of New Liquidity Facilities}

We now assess the implications for Federal Reserve income of the new and expanded liquidity facilities from August 2007 through December 2009-the period of the facilities' greatest usage. The income effects of the facilities are fairly straightforward to analyze. Interest rate risk was relatively low because the loans were short term, mostly ranging from overnight to three months. Credit risk was managed through the short term of the loans, the restriction of

\footnotetext{
${ }^{4}$ Nonetheless, total Federal Reserve assets did not change much over 2009, as the decline in the liquidity facilities was largely offset by the increase in assets acquired through the asset purchase programs.

${ }^{5}$ In May 2010, the Fed reauthorized dollar liquidity swap lines with several foreign central banks through January 2011. In December 2010, authorization was extended through August 1,2011.
}

Chart 1

\section{Evolution of Federal Reserve Assets}

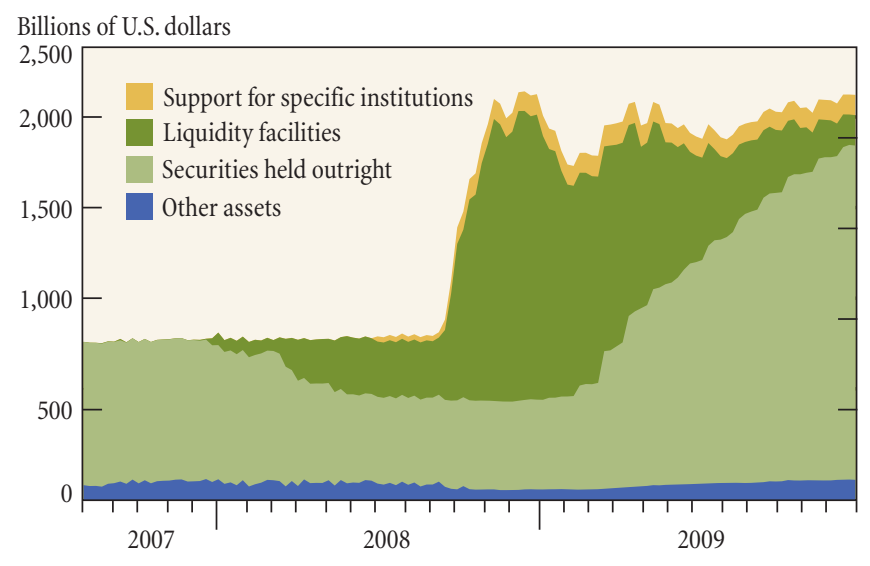

Source: Authors' calculations, based on data from the Federal Reserve System.

\section{Chart 2 \\ Evolution of Federal Reserve Liquidity Facilities}

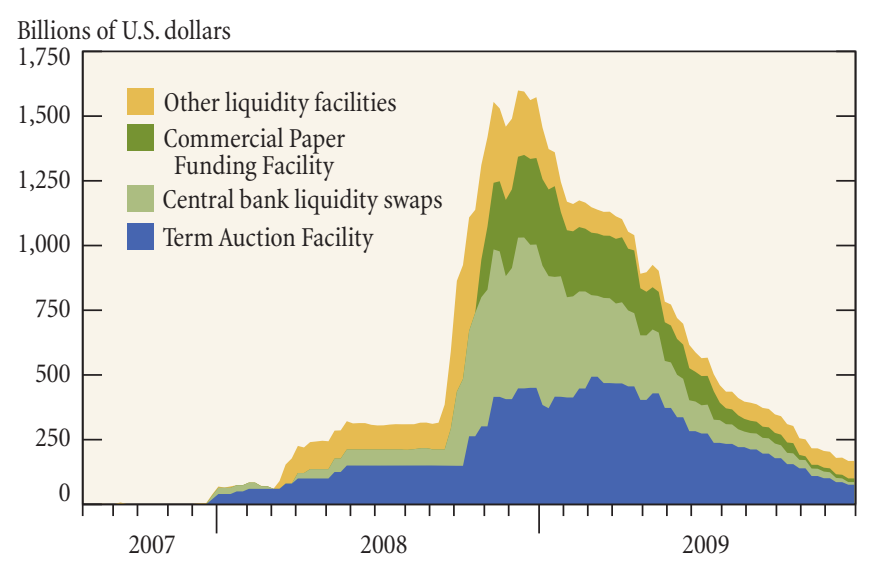

Source: Authors' calculations, based on data from the Federal Reserve System.

lending to institutions that met eligibility criteria, and the requirement that loans be backed by adequate collateral.

We conduct our analysis of income on a daily basis using publicly available data. The data come from the Fed's weekly statistical release H.4.1, "Factors Affecting Reserve Balances," which reports amounts outstanding for the facilities; from the Fed's websites for various auction facilities, which report rate and sometimes quantity information; and from the websites of foreign central banks, which report loans of U.S. dollars funded through the central bank swap lines. We also use rate information from Bloomberg to estimate income and the Fed's cost of funds.

Our analysis covers all dollar funding liquidity facilities. We exclude regular OMOs, which are used to implement interest rate policy rather than to mitigate liquidity disruptions, as well as the Fed's traditional securities lending facility, which is designed to 
mitigate disruptions in the securities lending market as opposed to the dollar funding markets. Because we focus on liquidity facilities, we do not assess the income effects of the Fed's asset purchase programs or its support for specific institutions. Furthermore, our analysis only considers interest and fee income.

\section{Income Estimation}

Income is perhaps easiest to estimate for several of the Federal Reserve's standing liquidity facilities, including the AMLF, discount window, and PDCF. Daily income for each facility is calculated as the amount outstanding for the facility on a given day times the prorated primary credit rate that day. For example, on October 20, 2008 , there was about $\$ 111.3$ billion outstanding through the PDCF (including transitional credit extensions) and the primary credit rate was 1.75 percent, so the Fed's earnings from the facility that day are calculated as $\$ 5.33$ million, where $\$ 5.33$ million $=\$ 111.3$ billion $\times$ 1.75 percent $\times 1$ day $/ 365$ days. $^{6}$

Income is also fairly easy to compute for many of the auction facilities. For the TAF, income is calculated as the amount outstanding on a given day times the prorated, weighted stop-out rate associated with the outstanding loans. On May 1, 2008, for example, $\$ 100$ billion in TAF loans was outstanding and the weighted stopout rate associated with these loans was 2.845 percent, reflecting $\$ 50$ billion lent at 2.82 percent on April 10 and $\$ 50$ billion lent at 2.87 percent on April 24. The Fed's earnings associated with TAF lending that day were thus $\$ 7.79$ million, where $\$ 7.79$ million $=$ $\$ 100$ billion $\times 2.845$ percent $\times 1$ day/365 days.

Income is calculated similarly for single-tranche OMOs, except that weighted-average interest rates are used instead of stop-out rates, reflecting the fact that funds were allocated through multipleprice auctions in this program instead of through single-price auctions as in the TAF. ${ }^{7}$ Swap line income is also calculated in the same way, taking into account whether foreign central banks offered funds at fixed subscription rates or through single- or multiple-price auctions. (The Fed's counterparties in these operations were the

\footnotetext{
${ }^{6}$ Note that amounts outstanding for these facilities were not publicly available on a daily basis when this article was being written, so we approximate the amount for any given day as the average amount outstanding over the week including that day. Also note that we credit the Fed's earnings over the term of a loan from the day following loan commencement through maturity—on October 21, 2008, in this case. For the AMLF, the appropriate discount rate to apply depends on when the lending was initiated, but that information was also not publicly available when this article was being written, so we use the discount rate contemporaneous to the amounts outstanding. For the PDCF, we ignore frequency-based fees, which, as of February 3, 2009, went into effect if a dealer accessed the facility on more than forty-five business days. For the discount window, we use the secondary credit rate and seasonal credit rate for the relatively small amounts lent through the secondary and seasonal credit facilities, respectively.

${ }^{7}$ In a single-price auction, every winning bidder pays the same rate, which is the marginal, or stop-out, rate, regardless of its bid. In a multiple-price auction, winning bidders pay their bid rates. In fixed-price subscriptions, bidders indicate the quantity of funds they want at rates fixed by the lender, and funds are allocated in proportion to bid amounts if an auction is oversubscribed. We also account for differences in interest rate quoting conventions when estimating income. While the primary credit rate is annualized using a 365-day year, commercial paper rates and repo rates are annualized using a 360-day year. Moreover, commercial paper rates are quoted on a discount basis.
}

foreign central banks, but the foreign central banks generally paid an interest rate on their borrowings from the Fed that reflected the income they earned in lending dollars to financial institutions in their jurisdictions.) Income from TSLF operations is also calculated like income from TAF operations, taking into consideration the fact that fees were based on the market values of the borrowed Treasury securities and not the par values.

For the TSLF option program, income takes two forms. There is income associated with the sale of the options, calculated-for days when the underlying loan could be outstanding — as the quantity of options sold times the prorated, weighted stop-out rates associated with the option sales. In addition, if the options were exercised, there is income based on the strike price and the quantity of options exercised. In both cases, the calculations account for the fact that fees were based on the market values of the borrowings rather than the par values.

$\mathrm{CPFF}$ income is more challenging to estimate. One source of income is the interest and fees received on purchased paper. The interest rate for new paper varied by day, depending on the overnight index swap (OIS) rate and the commercial paper type. Unsecured commercial paper was priced at the three-month OIS rate + 100 basis points, and was subject to an additional surcharge of 100 basis points per annum unless the paper was secured or guaranteed to the Federal Reserve's satisfaction. Asset-backed commercial paper was priced at the three-month OIS rate +300 basis points.

We make various assumptions to estimate CPFF interest and fee income. We approximate the split between unsecured and assetbacked commercial paper using the breakdowns given by the Fed in various reports. ${ }^{8}$ Interest income is then calculated based on average amounts outstanding each week and the weighted-average issuance rates associated with the amounts outstanding. ${ }^{9}$ We assume that 90 percent of unsecured paper was subject to the surcharge, which generates fee income equal to that reported in CPFF financial statements for 2008 (that is, \$290 million) given our other assumptions.

In addition to the interest and fee income directly tied to paper issuance, the Fed collected registration fees from issuers participating

\footnotetext{
${ }^{8}$ Financial statements for the CPFF report that 63.8 percent of the paper was unsecured as of December 31,2008, and various issues of the Federal Reserve System monthly report "Credit and Liquidity Programs and the Balance Sheet" indicate that 36.1 percent of the paper was unsecured as of May 27, 2009, 37.2 percent as of June 24, 2009, 27.0 percent as of July 29, 2009, 28.9 percent as of August 26, 2009, 29.7 percent as of September 30, 2009, 26.7 percent as of October 28, 2009, 20.0 percent as of November 25, 2009, and 22.2 percent as of December 30, 2009. We apply the 63.8 percent figure to amounts outstanding until December 31,2008 , and linearly interpolate the percentages for dates between December 31, 2008, and December 30,2009, making use of the reported observations for the intermediate dates.

${ }^{9}$ Averages for the first week of the program, when outstanding amounts rose quickly, are based on the part of the week the program was in operation. Weighted-average issuance rates depend on average issuance rates for a given week and the amount of outstanding paper estimated to have been issued that week, as calculated from end-of-week data. To simplify the analysis, we assume that paper generally matured after exactly thirteen weeks (ninety-one days). In practice, the stated maturity of the purchased paper was ninety days, although the actual maturity varied slightly if the maturity would otherwise occur on a weekend or holiday. In some instances, we assume that paper matured in the twelfth week after issuance to ensure that the amount of paper calculated to mature in a week was never less than the decline in the amount of paper outstanding.
} 
in the program. The one-time registration fees of 10 basis points were based on total possible issuance to the facility at a given time, which equaled the greatest amount of paper the issuer had outstanding over the first eight months of 2008. Financial statements for the CPFF indicate that $\$ 830$ million in registration fees was paid in 2008 . We amortize the $\$ 830$ million over the life of the program assuming that all the fees were paid when the program started and that no further fees were paid in 2009. ${ }^{10}$

TALF income is also more challenging to estimate. Lending rates for a given operation depended on the collateral backing the assetbacked securities, whether the loan was fixed rate or floating rate, and - if fixed rate- the term of the loan (three years or five years). We make various assumptions to simplify the estimation, including the assumptions that loans backed by a particular collateral type were either all fixed rate or all floating rate and that all fixed-rate loans were for three years. ${ }^{11}$

We then estimate TALF income based on the quantity of loans outstanding and the weighted-average lending rates associated with the outstanding loans. The weights are based on settled loan amounts and are not adjusted to reflect loan amortization, which occurs as the underlying loans are paid off. An additional source of income is the administrative fee imposed by the Fed, which equals 5 to 20 basis points of the loan amount. We amortize the fee over a three-year period.

\section{Estimation of Cost of Funds}

Through October 8, 2008, we estimate the cost of funds for the liquidity programs using the yield on the three-month Treasury bill. We do this for two reasons. First, the initial growth of the facilities in 2008 was funded by the Fed's divestment of most of its Treasury bill portfolio, whereby the Fed either sold its outstanding bills or chose not to reinvest the proceeds of maturing bills into new ones. As a result, the Fed's bill portfolio dropped from $\$ 277$ billion on August 22, 2007 , to $\$ 18$ billion on September 24, 2008. The bills in the portfolio had ranged in maturity from zero to fifty-two weeks, with most concentrated in the range of zero to twenty-six weeks.

Second, when lending through the liquidity facilities expanded sharply in fall 2008, the reserve effects were offset through the

\footnotetext{
${ }^{10}$ In fact, financial statements for 2009 imply that an additional \$19 million in registration fees was paid that year. Our amortization period initially runs through July 30,2009, thirteen weeks after the originally announced program expiration date of April 30, 2009. On February 3, 2009, the program was extended to October 30, 2009, and on June 25, 2009, it was extended to February 1, 2010. The amortization periods were extended accordingly, on those dates, for registration fees not yet earned.

11 Specifically, we assume that loans to finance ABS backed by auto loans, commercial mortgage loans, equipment loans, and loans guaranteed by the Small Business Administration were fixed rate and that loans to finance ABS backed by credit card loans, floorplan loans, insurance premium finance loans, residential mortgage servicing advances, and student loans were floating rate. We also assume, when applicable, that the average life of the collateral backing the fixed-rate loans was at least two years and that student loan collateral was not government guaranteed and did not have a coupon rate tied to the prime rate. Note that detailed TALF loan data were not publicly available when this article was being written.
}

Chart 3

\section{Evolution of Federal Reserve Liabilities and Capital}

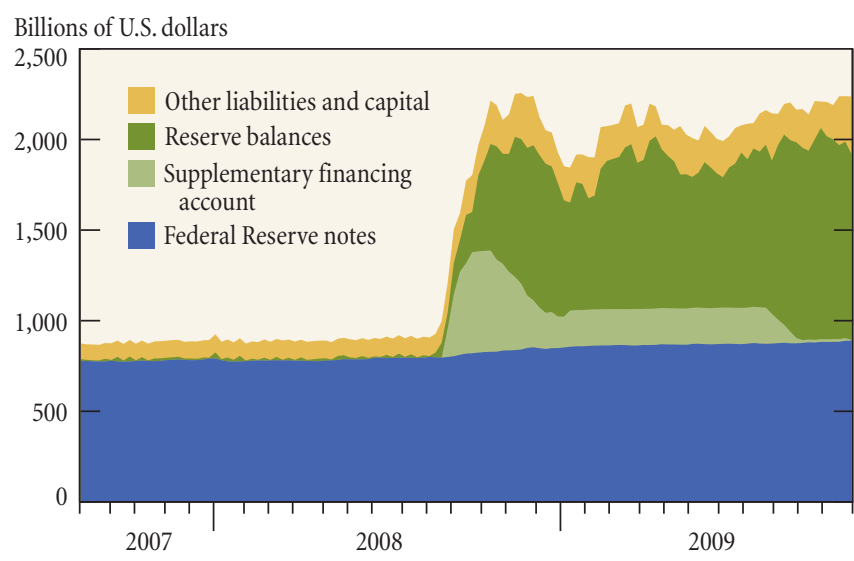

Source: Authors' calculations, based on data from the Federal Reserve System.

Treasury's new Supplemental Financing Program, announced September 17,2008. Through the program, the Treasury issues so-called supplementary financing bills and deposits the proceeds with the Fed. ${ }^{12}$ The quantity of such bills outstanding peaked at $\$ 559$ billion in fall 2008 (Chart 3). The maturity of the bills has ranged between 7 and 101 days.

From October 9,2008, we estimate the cost of funds for the liquidity programs using the interest rate on excess reserve balances. The Fed began paying interest on reserves that day, and interestbearing reserves quickly became the primary way through which the Fed financed its expanded balance sheet. Reserve balances at the Fed were $\$ 176$ billion on October 8, 2008, but had averaged a much lower $\$ 19$ billion over the calendar year to date. Such reserves grew to $\$ 856$ billion by the end of 2008 and stood at $\$ 1,025$ billion on December 30, 2009.

Another way to think of the cost of funds is to consider the characteristics of the assets being financed. The liquidity facilities provided mostly short-term financing, ranging from overnight to three months, for all but the AMLF and TALF. Moreover, the credit risk associated with the lending was managed to relatively low levels, through program terms. The three-month Treasury bill yield and the interest rate on reserves are thus reasonably close references in terms of maturity and credit risk to benchmark the performance of the liquidity facilities.

The cost of funds for a particular facility on a given day is estimated as the amount outstanding under the facility that day times the applicable prorated interest rate for that day. On October 20,2008, for example, the interest rate on excess reserves was 0.75 percent, so the cost of funds associated with the $\$ 111.3$ billion outstanding under the PDCF that day is estimated as $\$ 2.3$ million, where $\$ 2.3$ million equals $\$ 111.3$ billion $\times 0.75$ percent $\times 1$ day $/ 360$ days.

\footnotetext{
12 Although interest on the bills is paid by the Treasury, and not the Fed, we consider the cost of the bill issuance in order to present a complete accounting of the funding costs associated with the facilities.
} 
Table 1

\section{Federal Reserve Liquidity Facility Income by Period}

Millions of Dollars

\begin{tabular}{lccc} 
Period & $\begin{array}{c}\text { Interest/ } \\
\text { Fee Income }\end{array}$ & $\begin{array}{c}\text { Cost of Funds } \\
\text { Fee Income }\end{array}$ \\
\hline 2007 (Aug. 9 - Dec. 31) & 92 & 62 & 30 \\
2008 (Jan. 1 - Dec. 31) & 11,668 & 5,057 & 6,611 \\
2009 (Jan. 1 - Dec. 31) & 8,016 & 1,738 & 6,278 \\
Total & 19,775 & 6,856 & 12,919
\end{tabular}

Source: Authors' estimates, based on data from Bloomberg L.P., the Federal Reserve System, and foreign central banks.

Note that our cost of funds estimation is concerned with economic costs and not accounting costs. We thus consider the opportunity cost of lost interest income when the initial growth of the liquidity facilities was offset by the Fed's sale or redemption of Treasury bills. Also note that estimation of the cost of funds is not pertinent to the TSLF and TOP, through which the Fed lent securities instead of cash. When securities were lent through those programs, the Fed maintained the right to the interest generated by the securities. As a result, the cost of lending the securities was close to zero. ${ }^{13}$

\section{Findings}

We find that the Federal Reserve's new and expanded liquidity facilities contributed about $\$ 19.8$ billion to Federal Reserve interest and fee income between August 9, 2007, and December 31, 2009 (Table 1). We estimate the cost of funds for these facilities at $\$ 6.9$ billion over this period, implying a net contribution from the facilities of $\$ 12.9$ billion. For 2008 , in particular, the gross contribution was $\$ 11.7$ billion, accounting for 26 percent of the Reserve Banks' $\$ 44.9$ billion income before expenses that year.

The central bank liquidity swaps, CPFF, and TAF alone accounted for an estimated $\$ 15.6$ billion of income, or almost four-fifths of total income from the liquidity facilities (Table 2). The CPFF was the largest contributor, producing gross and net income of $\$ 5.9$ billion and $\$ 5.3$ billion, respectively. Interestingly, the CPFF was only the thirdlargest liquidity facility in terms of average amount outstanding over the sample period, but it generated high income because of the wide spreads and fees required to participate in the program.

Other income estimates to note are those for the TSLF and TOP, for which net income equaled gross income, given that there was no cost of funds. The MMIFF was never utilized, and thus had gross and net income of zero.

The facilities' contributions to Federal Reserve income varied considerably over time, reflecting variations in program structures and market conditions (Chart 4). A comparison with amounts out-

\footnotetext{
13 The securities lending (TSLF and TOP) did put an encumbrance on the Fed's balance sheet in the sense that securities out on loan could not be sold. The Fed also took on credit risk by engaging in the loans, although it managed such risk by specifying the quality of collateral it would accept, imposing haircuts on such collateral, requiring that the collateral be revalued on a daily basis, limiting the range of its counterparties, and imposing per-dealer borrowing limits.
}

Table 2

\section{Federal Reserve Liquidity Facility Income by Facility} Millions of Dollars

\begin{tabular}{|c|c|c|c|}
\hline Facility & $\begin{array}{c}\text { Interest/ } \\
\text { Fee Income }\end{array}$ & Cost of Funds & $\begin{array}{l}\text { Net Interest/ } \\
\text { Fee Income }\end{array}$ \\
\hline $\begin{array}{l}\text { Asset-Backed Commercial Paper } \\
\text { Money Market Mutual Fund } \\
\text { Liquidity Facility }\end{array}$ & 380 & 172 & 208 \\
\hline Central bank liquidity swaps & 5,543 & 1,793 & 3,750 \\
\hline Commercial Paper Funding Facility & 5,937 & 650 & 5,287 \\
\hline Discount window & 744 & 410 & 334 \\
\hline $\begin{array}{l}\text { Money Market Investor Funding } \\
\text { Facility }\end{array}$ & 0 & 0 & 0 \\
\hline Primary Dealer Credit Facility & 546 & 254 & 292 \\
\hline $\begin{array}{l}\text { Single-tranche open market } \\
\text { operations }\end{array}$ & 1,277 & 787 & 489 \\
\hline $\begin{array}{l}\text { Term Asset-Backed Securities } \\
\text { Loan Facility }\end{array}$ & 436 & 59 & 377 \\
\hline Term Auction Facility & 4,131 & 2,732 & 1,399 \\
\hline Term Securities Lending Facility & 777 & 0 & 777 \\
\hline $\begin{array}{l}\text { Term Securities Lending Facility } \\
\text { Options Program }\end{array}$ & 6 & 0 & 6 \\
\hline Total & 19,775 & 6,856 & 12,919 \\
\hline
\end{tabular}

Source: Authors' estimates, based on data from Bloomberg L.P., the Federal Reserve System, and foreign central banks.

Note: Actual income figures for many of the facilities are available in the Federal Reserve's annual report and in its monthly report "Credit and Liquidity Programs and the Balance Sheet."

standing over time (Chart 2) shows the outsized effects of the CPFF on income and how TAF income declined sharply, even as outstanding amounts under the TAF remained high. The drop in TAF income reflects the fact that every TAF auction in 2009 stopped out at the minimum auction fee of 25 basis points, whereas earlier auctions stopped out at rates as high as 4.67 percent.

The cost of funds relative to income also varied significantly over time, reflecting variation in Treasury bill rates, the interest rate on reserves, and the rates at which the Fed lent money through the facilities (Chart 5). The CPFF, in particular, provided funds at wide spreads to the interest rate on reserves, contributing to the sizable differential between gross income and the cost of funds after the CPFF's launch in October 2008. The sharp decline in the cost of funds in early December 2008 reflects the reduction from 1 percent to 0.25 percent in the interest rate on excess reserves at that time.

\section{Comparison with Figures Released by the Fed}

In cases where our estimates can be compared with figures in the Fed's official reports, the numbers are quite similar. For 2008, a comparison of the Fed's reported figures and our estimates, in italics, shows a close similarity across six facilities: AMLF ( $\$ 470$ million, $\$ 341$ million), central bank liquidity swaps ( $\$ 3,606$ million, $\$ 3,334$ million), CPFF ( $\$ 1,707$ million, $\$ 1,724$ million), discount window (\$512 million, \$511 million), PDCF (\$511 million, \$508 million), and TAF ( $\$ 3,305$ million, $\$ 3,306$ million). 
Chart 4

\section{Federal Reserve Liquidity Facility Income by Week}

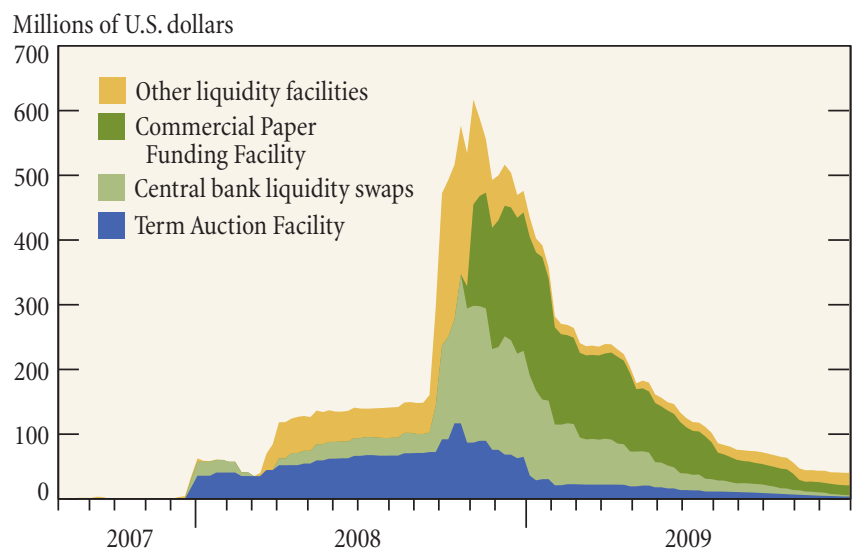

Source: Authors' estimates, based on data from Bloomberg L.P., the Federal Reserve System, and foreign central banks.

For 2009, a close similarity is also evident across seven facilities: AMLF ( $\$ 73$ million, $\$ 39$ million), central bank liquidity swaps (\$2,168 million, \$2,184 million), CPFF (\$4,224 million, $\$ 4,213$ million), discount window (\$204 million, \$204 million), PDCF

(\$36 million, \$38 million), TAF (\$786 million, \$787 million), and TALF (\$468 million, \$436 million). ${ }^{14}$

In sum, for the numbers that are directly comparable, the Fed reports interest and fee income from the liquidity facilities that is $\$ 445$ million higher than our estimates. It follows that if one employs the official income figures reported by the Fed, supplemented by our estimates for facilities not broken out in the Fed's reports, then the estimated income from the facilities between August 2007 and December 2009 is $\$ 20.2$ billion instead of $\$ 19.8$ billion. Income exceeding our cost of funds estimate is then $\$ 13.4$ billion, instead of $\$ 12.9$ billion.

\section{Conclusion}

The Federal Reserve's new or expanded liquidity facilities were profitable, contributing an estimated $\$ 20$ billion to the central bank's

\footnotetext{
14 Our AMLF estimates are low because they apply the contemporaneous discount rate to amounts outstanding, whereas the actual rate paid depended on the discount rate at the time the loan was initiated. As we observed, information on when lending was initiated under the AMLF was not publicly available when this article was being written. These TALF figures include interest income and administrative fees, and do not reflect the effects of TALF LLC.
}

Chart 5

\section{Gross versus Net Liquidity Facility Income by Week}

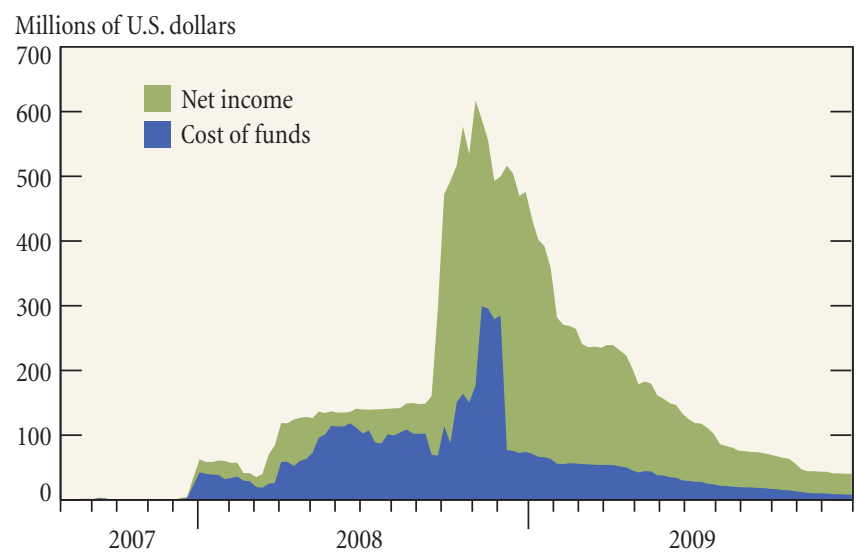

Source: Authors' estimates, based on data from Bloomberg L.P. , the Federal Reserve System, and foreign central banks.

interest and fee income between August 2007 and December 2009, even as they mitigated disruptions in the dollar funding markets. The cost of the lent funds amounted to only an estimated $\$ 7$ billion, so that the facilities generated an estimated $\$ 13$ billion in income above the cost of funds. Moreover, the credit risk that came with the additional income was kept to a minimum by the numerous steps taken by the Fed to limit such exposure.

To evaluate the implications of all of the Federal Reserve's actions during the crisis, one should also consider its support for specific institutions and its direct purchases of assets. These other efforts had different risk characteristics and-given their different purposeswere not designed to wind down as quickly as the facilities; thus, they are better evaluated over a longer time period. Our study, focusing exclusively on the liquidity facilities, concludes that the initiatives had a clear positive effect on Federal Reserve income.

\section{References}

Cecchetti, Stephen G. 2009. "Crisis and Responses: The Federal Reserve in the Early Stages of the Financial Crisis." Journal of Economic Perspectives 23, no. 1 (winter): 51-75.

Willardson, Niel, and LuAnne Pederson. 2010. “Federal Reserve Liquidity Programs: An Update." Federal Reserve Bank of Minneapolis, The Region, June: $14-25$.

\section{ABOUT THE AUTHORS}

Michael J. Fleming is a vice president in the Research and Statistics Group of the Federal Reserve Bank of New York; Nicholas J. Klagge is a financial/economic analyst in the Bank's Credit and Payments Risk Group.

Current Issues in Economics and Finance is published by the Research and Statistics Group of the Federal Reserve Bank of New York. Linda Goldberg and Erica L. Groshen are the editors.

The views expressed in this article are those of the authors and do not necessarily reflect the position of the Federal Reserve Bank of New York or the Federal Reserve System. 